\title{
Apolipoprotein E Gene Variants and Risk of Coronary Heart Disease: A Meta-Analysis
}

\author{
Min Xu, ${ }^{1}$ Jun Zhao, ${ }^{2,3}$ Yu Zhang, ${ }^{4}$ Xu Ma, ${ }^{2,3}$ Qiaoyun Dai, ${ }^{3}$ Hong Zhi, \\ Bei Wang, ${ }^{1}$ and Lina Wang ${ }^{1}$ \\ ${ }^{1}$ Key Laboratory of Environmental Medicine Engineering, Ministry of Education, Department of Epidemiology and Biostatistics, \\ School of Public Health, Southeast University, Nanjing, China \\ ${ }^{2}$ Graduate School of Peking Union Medical College, Beijing, China \\ ${ }^{3}$ National Research Institute for Family Planning, Beijing, China \\ ${ }^{4}$ Centers for Disease Control and Prevention, Zhejiang, China \\ ${ }^{5}$ Department of Cardiology, ZhongDa Hospital, Southeast University, Nanjing, Jiangsu, China
}

Correspondence should be addressed to Lina Wang; lnwang@seu.edu.cn

Received 16 August 2016; Accepted 9 October 2016

Academic Editor: Hai-Feng Pan

Copyright (C) 2016 Min Xu et al. This is an open access article distributed under the Creative Commons Attribution License, which permits unrestricted use, distribution, and reproduction in any medium, provided the original work is properly cited.

Objectives. Apo E genes involved in lipoprotein synthesis and metabolism are considered one of the candidates to CHD. However, the results remain conflicting. Methods. We performed this meta-analysis based on 30 published studies including 11,804 CHD patients and 17,713 controls. Results. Compared with the wild genotype E3/3, the variant genotypes ApoEE3/4 and E4/4 were associated with $22 \%$ and $45 \%$ increased risk of $\mathrm{CHD}$, respectively (E3/4 versus $\mathrm{E} 3 / 3: \mathrm{OR}=1.22,95 \% \mathrm{CI}=1.15-1.29 ; \mathrm{E} 4 / 4$ versus $\mathrm{E} 3 / 3$ : $\mathrm{OR}=1.45,95 \%$ $\mathrm{CI}=1.23-1.71)$. Besides, compared with $\varepsilon 3$ allele, carriers with the $\varepsilon 4$ allele had a $46 \%$ increased risk of $\mathrm{CHD}(\mathrm{OR}=1.46,95 \% \mathrm{CI}=$ $1.28-1.66)$, while the $\varepsilon 2$ had no significantly decreased risk of CHD. In the subgroup analysis by ethnicity, $\varepsilon 4$ had a $25 \%$ increased risk of CHD in Caucasians ( $\mathrm{OR}=1.25,95 \% \mathrm{CI}=1.11-1.41)$, and the effects were more evident in Mongolians $(\mathrm{OR}=2.29,95 \% \mathrm{CI}$ $=1.89-2.77)$. The $\varepsilon 2$ allele had a decreased risk of CHD in Caucasians $(\mathrm{OR}=0.84,95 \% \mathrm{CI}=0.74-0.96)$, but not in Mongolians. Conclusions. The analysis suggested that $A p o E \varepsilon 4$ mutation was associated with the increased risk of CHD, while ApoEv2 allele had a decreased risk of CHD just in Caucasians.

\section{Introduction}

Coronary heart disease (CHD) as a multifactorial disease caused by genetic and environmental factors became one of the leading causes of mortality and morbidity worldwide, especially in the developed countries [1]. Previous studies provided evidence that risk factors for CHD, including diabetes mellitus, smoking, and arterial hypertension, would contribute to rapid process of clinical events such as myocardial infarction (MI), ischemic heart failure, and death $[2,3]$. Moreover, apart from the above risk factors, population-based studies have reported that genetic susceptibility accounts for around $50 \%$ of the risk for CHD, which suggested that the host genetic background plays an important role in the onset and development of CHD as well $[4,5]$. The determination of blood lipid and lipoprotein levels is one of the coronary risk factors. Apolipoprotein genes involved in lipoprotein synthesis and metabolism play imperative roles in studying the susceptibility to $\mathrm{CHD}$ and cerebrovascular disease [6-11].

In 1992, Dallongeville et al. tested the consistent relationship between plasma TG levels and Apo E phenotype among 45 different populations in a meta-analysis [12]. Another meta-analysis including 14 studies showed that subjects with $\varepsilon 4$ allele were associated with $26 \%$ increased risk of CHD compared with $\varepsilon 3$ allele [13]. Since the publication of these two meta-analyses, numerous studies have appeared in recent years [14-17]. However, differences in study design, end point validation, choice of subjects, and limited statistical power have led to different results of Apo E genotypes on CHD risk in the general population. Therefore, the present metaanalysis is designed to derive a more plausible estimation. 


\section{Methods}

2.1. Studies Selection. We search the electronic databases PubMed, Web of Science, Embase, Wanfang, China National Knowledge Internet (CNKI), and VIP for relevant English language articles from Jan 1, 2000, to Mar 1, 2016, using the following index terms: Apo $E$ and polymorphism(s) single nucleotide polymorphism (SNP), variant, mutation and coronary artery disease, coronary heart disease, CAD, and CHD. Hand searches were also performed.

2.2. Inclusion Criteria. The inclusion criteria were as follows: (1) Apo E gene polymorphism in CAD or CHD; (2) casecontrol studies; (3) studies with full-text articles; (4) sufficient data for calculating an odds ratio (OR) with $95 \%$ confidence interval (CI); (5) not republished data.

2.3. Data Extraction. All the data were carefully extracted from all eligible publications independently by two authors. The following information was collected: the first author's name, date of publication, country, study design, major CHD end point, selection of the controls, genotyping methods, allele frequencies of $\varepsilon 2, \varepsilon 3$, and $\varepsilon 4$, and genotype distribution in case-patients and controls. Definition of CHD end points includes $\mathrm{MI}$, angina pectoris, percutaneous transluminal coronary angioplasty, coronary artery bypass graft surgery, and severe stenosis on coronary angiography. In most studies that included case-patients with coronary artery disease, diagnosis was based on angiographically documented luminal stenosis $(\geq 50 \%)$ in at least 1 of the 3 major coronary arteries.

2.4. Quality Score Assessment. To determine the methodological quality of each study, we used the Newcastle-Ottawa scale (NOS). The NOS ranges between zero (worst) up to nine stars (best). Two authors of this article independently assessed the qualities of included studies. Disagreement was resolved by discussion.

2.5. Meta-Analysis. The risks (odds ratios, ORs) of CHD associated with the Apo E polymorphisms were estimated for each study with the software Stata12.0. The risk of the variant genotypes E2/2, E2/3, E2/4, E4/3, and E4/4 was estimated compared with the genotype E3/3 homozygotes. In addition to comparisons for total subjects, studies were categorized into different subgroup analyses according to the ethnicity. We estimated the between-study heterogeneity across the eligible comparisons using the Cochrane $Q$-test and the heterogeneity was considered significant for $P<0.1$. Fixed effect or random effect was used to calculate pooled effect estimates. Random effects incorporate an estimate of the between-study variance and tend to provide wider confidence intervals, when the results of the constituent studies differ among themselves. In the absence of between-study heterogeneity, the two methods provide identical results.

Publication bias was evaluated by funnel plot and Begg's and Egger's tests. The Hardy-Weinberg equilibrium (HWE) was tested by a goodness-of-fit $\chi^{2}$ test to compare the observed genotypes frequencies with the expected ones

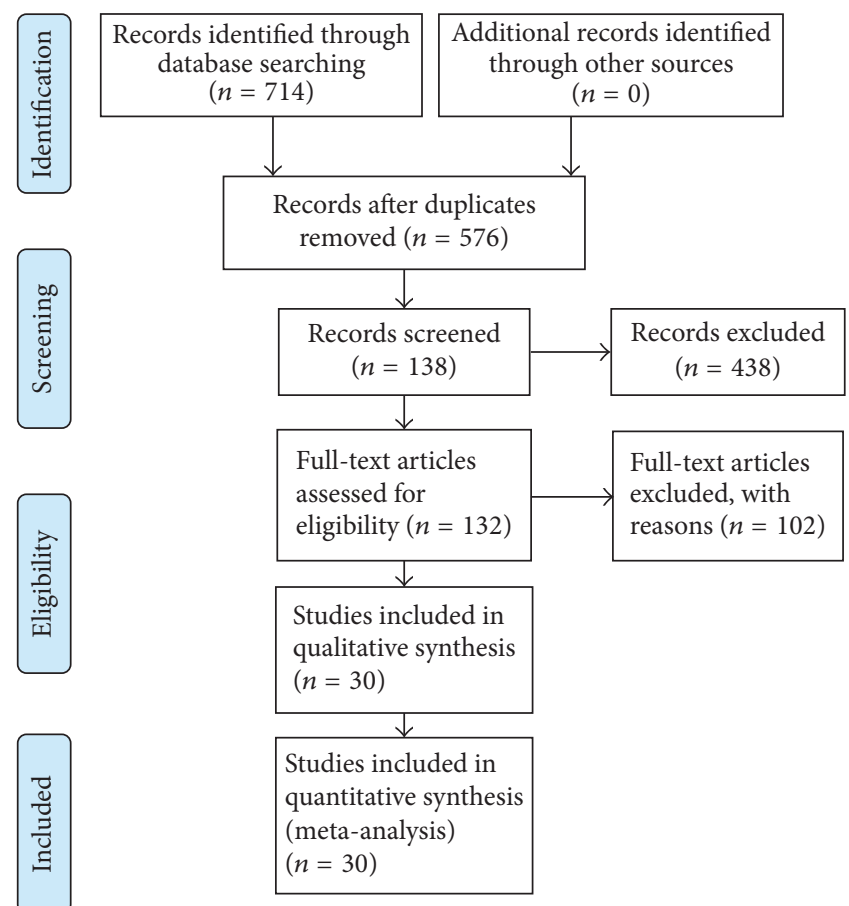

Figure 1: The flow diagram of study selection.

among control subjects. For sensitivity analyses, we examined whether the excluding studies with substantial deviation from HWE among controls affected our pooled estimates of ORs.

Finally, we use the following formula to estimate the failsafe number:

$$
\begin{aligned}
& \mathrm{N}_{\mathrm{fs}}(0.05)=\left(\frac{\sum Z}{1.64}\right) \times 2-K, \\
& \mathrm{~N}_{\mathrm{fs}}(0.01)=\left(\frac{\sum Z}{2.33}\right) \times 2-K .
\end{aligned}
$$

$K$ is the number of included studies and $Z$ is the $Z$ value of the independent study. The result is obtained from the software SAS 9.2.

\section{Result}

3.1. Studies Characteristics. 714 studies were searched, among which 30 studies were included in the final meta-analysis [1847]. The study selection process is detailed in Figure 1.

Given in Table 1 were the lists of number of cases, controls, HWE, and the NOS score of these 30 case-control studies. All studies indicated that the distribution of genotypes in the controls was consistent with HWE, except for 7 studies [29, $35,37,39,40,45,46](P<0.05)$. According to the quality criteria, there were 21 studies with high quality (NOS score $>6$ ).

Tables 2 and 3 showed the frequency distributions of the Apo $E$ alleles and genotypes in the cases and controls.

3.2. Meta-Analysis Results. Figures 2 and 3 showed the ORs on CHD associated with ApoEc2 alleles and ApoEc4 alleles compared with the $\varepsilon 3$ alleles in individual studies. 


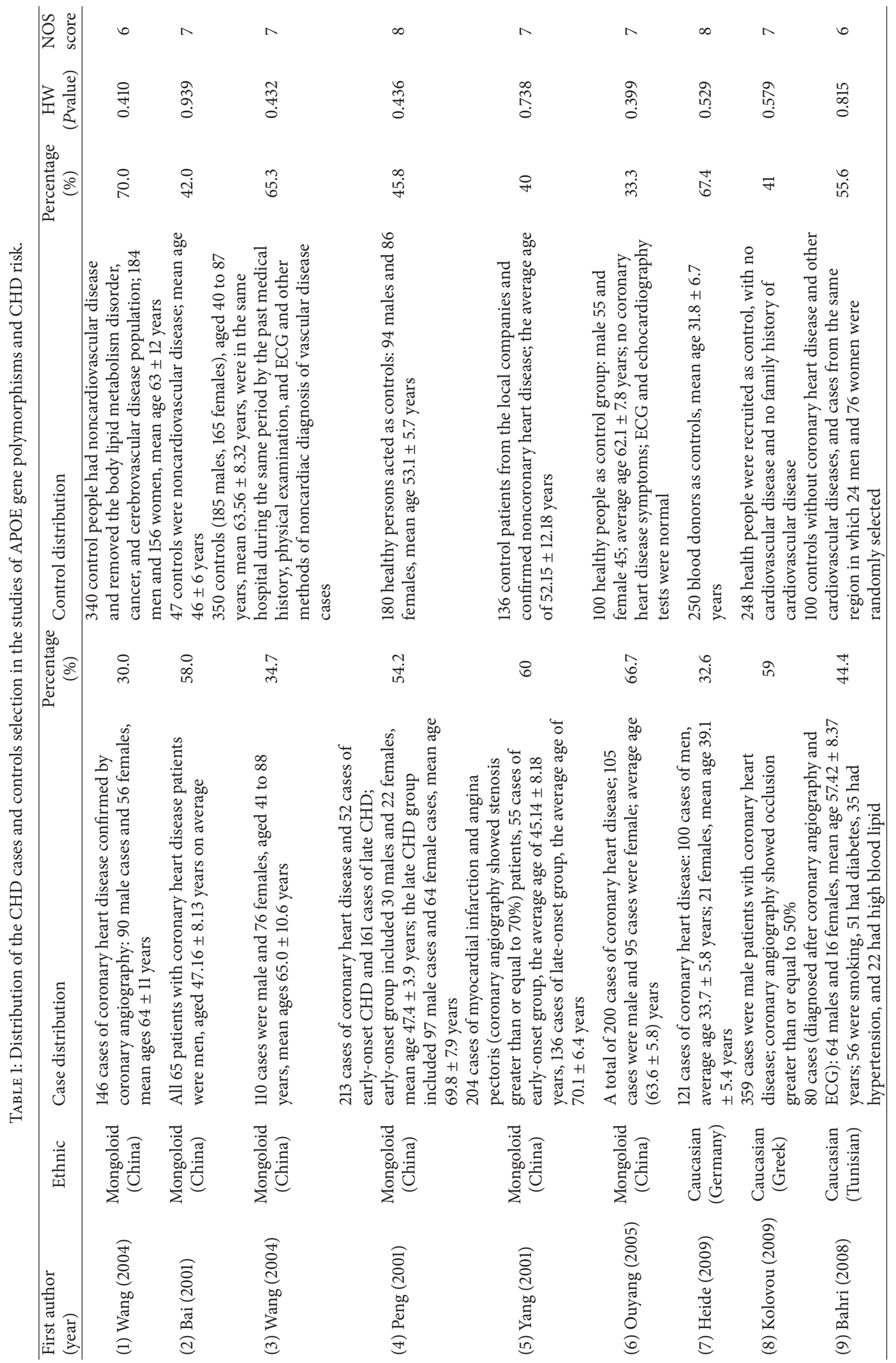




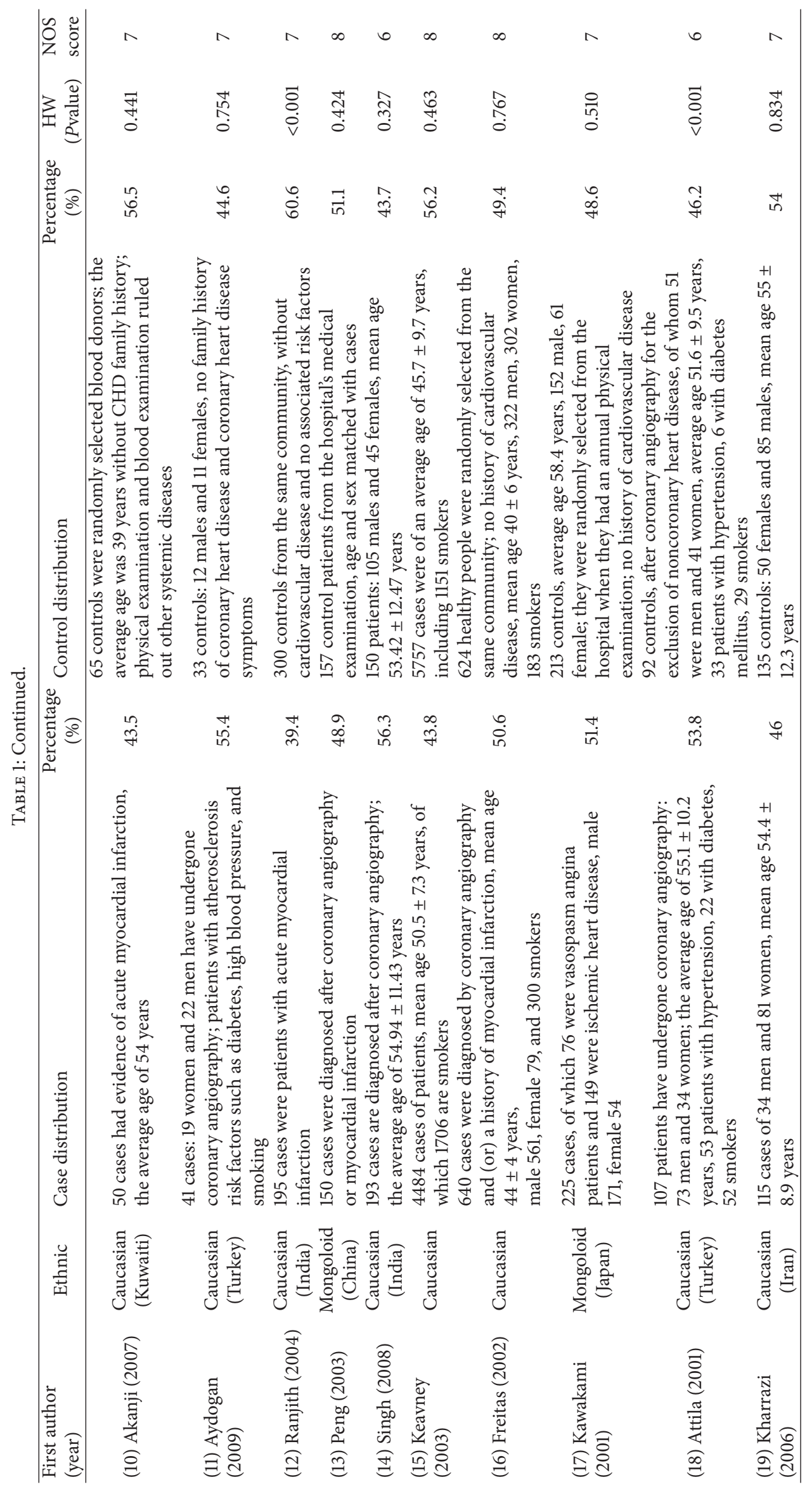




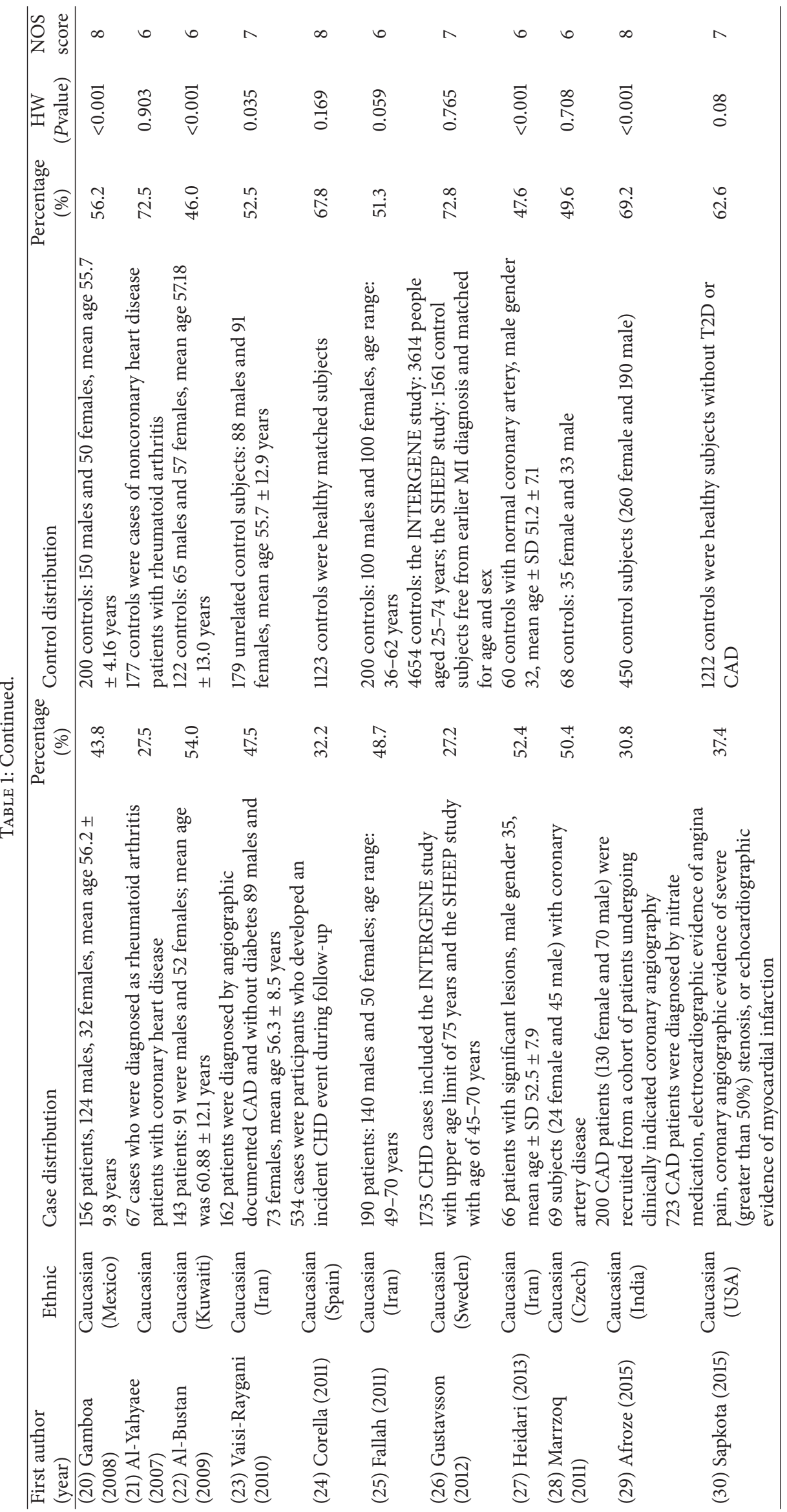


TABLE 2: Distribution of Apo E alleles in the case and control groups included in the meta-analysis.

\begin{tabular}{|c|c|c|c|c|c|c|c|}
\hline \multirow{4}{*}{ First author (year) } & \multirow{4}{*}{ Case/control $(N / N)$} & \multicolumn{6}{|c|}{ Distribution of apolipoprotein E alleles } \\
\hline & & \multicolumn{2}{|c|}{$\varepsilon 2$} & \multicolumn{2}{|c|}{$\varepsilon 3$} & \multicolumn{2}{|c|}{$\varepsilon 4$} \\
\hline & & Case & Control & Case & Control & Case & Control \\
\hline & & $N(\%)$ & $N(\%)$ & $N(\%)$ & $N(\%)$ & $N(\%)$ & $N(\%)$ \\
\hline (1) Wang (2004) & $292 / 680$ & $21(7.2)$ & $48(7.1)$ & $232(79.4)$ & $583(85.7)$ & $39(13.4)$ & $49(7.2)$ \\
\hline (2) Bai (2001) & $100 / 94$ & $4(4.0)$ & $5(5.3)$ & $90(90.0)$ & $86(91.5)$ & $6(6.0)$ & $3(3.2)$ \\
\hline (3) Wang (2004) & $372 / 700$ & $27(7.3)$ & $50(7.1)$ & $291(78.2)$ & $601(85.9)$ & $54(14.5)$ & $49(7.0)$ \\
\hline (4) Peng (2001) & $426 / 360$ & $34(8.0)$ & $30(8.3)$ & $328(77.0)$ & $303(84.2)$ & $64(15.0)$ & $27(7.5)$ \\
\hline (5) Yang (2001) & $408 / 272$ & $20(4.9)$ & $15(5.5)$ & $348(85.3)$ & $239(87.9)$ & $40(9.8)$ & $18(6.6)$ \\
\hline (6) Ouyang (2005) & $400 / 200$ & $31(7.7)$ & $18(9.0)$ & $291(72.8)$ & $167(81.5)$ & $78(19.5)$ & $19(9.5)$ \\
\hline (7) Heide (2009) & $242 / 500$ & $11(4.5)$ & $36(8.3)$ & $202(83.5)$ & $406(81.2)$ & $29(12.0)$ & $58(11.5)$ \\
\hline (8) Kolovou (2009) & $718 / 496$ & $37(5.2)$ & $39(7.9)$ & $612(85.2)$ & $414(83.4)$ & $69(9.6)$ & $43(8.7)$ \\
\hline (9) Bahri (2008) & $160 / 200$ & $6(3.7)$ & $9(4.5)$ & $140(87.6)$ & $174(87.0)$ & $14(8.7)$ & $17(8.5)$ \\
\hline (10) Akanji (2007) & $100 / 130$ & $6(6.0)$ & $9(6.9)$ & $87(87.0)$ & $108(83.1)$ & $7(7.0)$ & $13(10.0)$ \\
\hline (11) Aydogan (2009) & $82 / 46$ & $4(4.9)$ & $4(17.4)$ & $69(84.1)$ & $37(80.4)$ & $9(11.0)$ & $5(11.6)$ \\
\hline (12) Ranjith (2004) & $390 / 600$ & $10(2.6)$ & $27(4.5)$ & $330(84.6)$ & $517(86.2)$ & $50(12.8)$ & $56(9.3)$ \\
\hline (13) Peng (2003) & $300 / 314$ & $24(8.0)$ & $16(5.0)$ & $237(79.0)$ & $275(87.6)$ & $39(13.0)$ & $23(7.4)$ \\
\hline (14) Singh (2008) & $386 / 300$ & $21(5.4)$ & $23(7.7)$ & $307(79.5)$ & $257(85.6)$ & $58(15.1)$ & $20(6.7)$ \\
\hline (15) Keavney (2003) & $8968 / 11514$ & $609(6.8)$ & $911(7.9)$ & $6778(75.6)$ & $8830(76.7)$ & $1581(17.6)$ & $1773(15.4)$ \\
\hline (16) Freitas (2002) & $1280 / 1248$ & $61(4.8)$ & $90(7.2)$ & $1002(78.2)$ & $958(76.8)$ & $217(17.0)$ & $200(16.0)$ \\
\hline (17) Kawakami (2001) & $450 / 426$ & $13(2.9)$ & $15(3.5)$ & $390(86.7)$ & $349(81.9)$ & $47(10.4)$ & $62(14.6)$ \\
\hline (18) Attila (2001) & $214 / 184$ & $26(12.1)$ & $15(8.1)$ & $166(77.6)$ & $163(88.6)$ & $22(10.3)$ & $6(3.3)$ \\
\hline (19) Kharrazi (2006) & $230 / 270$ & $18(7.8)$ & $11(4.1)$ & $169(73.5)$ & $250(92.6)$ & $43(18.7)$ & $9(3.3)$ \\
\hline (20) Gamboa (2008) & $312 / 400$ & $5(1.6)$ & $9(2.2)$ & $283(90.7)$ & $364(91.0)$ & $24(7.7)$ & $27(6.8)$ \\
\hline (21) Al-Yahyaee (2007) & $134 / 354$ & $1(0.7)$ & $6(1.7)$ & $127(94.8)$ & $335(94.6)$ & $6(4.5)$ & $13(3.7)$ \\
\hline (22) Al-Bustan (2009) & $286 / 244$ & $21(7.4)$ & $23(9.4)$ & $246(86.0)$ & 207 (84.9) & $19(6.6)$ & $14(5.7)$ \\
\hline (23) Vaisi-Raygani (2010) & $324 / 357$ & $31(9.6)$ & $40(11.3)$ & $257(79.3)$ & $289(80.8)$ & $36(11.1)$ & $28(7.9)$ \\
\hline (24) Corella (2011) & $1035 / 2246$ & $42(4.1)$ & $123(5.5)$ & $891(86.1)$ & $1928(85.8)$ & $102(9.9)$ & $195(8.7)$ \\
\hline (25) Fallah (2011) & $380 / 400$ & $73(19.2)$ & $55(13.8)$ & $141(37.1)$ & $218(54.5)$ & $166(43.7)$ & $127(31.8)$ \\
\hline (26) Gustavsson (2012) & $3470 / 9308$ & $199(5.7)$ & $738(7.9)$ & $2672(77.0)$ & 7065 (75.9) & $599(17.3)$ & $1505(16.2)$ \\
\hline (27) Heidari (2013) & $132 / 122$ & $16(12.1)$ & $14(11.5)$ & $110(83.3)$ & $108(88.5)$ & $6(4.5)$ & $0(0)$ \\
\hline (28) Marrzoq (2011) & $138 / 136$ & $5(3.6)$ & $7(5.2)$ & $114(82.6)$ & $119(87.5)$ & $19(13.8)$ & $10(7.4)$ \\
\hline (29) Afroze (2015) & $400 / 900$ & $26(6.5)$ & $66(7.3)$ & $291(72.8)$ & $732(81.3)$ & $83(20.8)$ & $102(11.3)$ \\
\hline (30) Sapkota (2015) & $1446 / 2432$ & $52(3.6)$ & $95(3.9)$ & $1285(88.9)$ & $2174(89.4)$ & $109(7.5)$ & $163(6.7)$ \\
\hline
\end{tabular}

Overall, in the dominant model, individuals carrying the ApoEE2/2, E2/3, and E2/4 genotypes did not have significant risk of $\mathrm{CHD}$ compared with individuals with the $\mathrm{E} 3 / 3$ genotype $(\mathrm{E} 2 / 2$ versus $\mathrm{E} 3 / 3$ : $\mathrm{OR}=1.03,95 \% \mathrm{CI}=0.79-1.34$; $\mathrm{E} 2 / 3$ versus $\mathrm{E} 3 / 3$ : $\mathrm{OR}=0.89,95 \% \mathrm{CI}=0.76-1.06$; $\mathrm{E} 2 / 4$ versus $\mathrm{E} 3 / 3$ : $\mathrm{OR}=1.04,95 \% \mathrm{CI}=0.87-1.23)$, However, compared with E3/3 genotype, the variant genotypes ApoEE4/4 and $\mathrm{E} 3 / 4$ were associated with increased risk of CHD in 30 studies in the genetic models (E3/4 versus $\mathrm{E} 3 / 3$ : $\mathrm{OR}=1.48,95 \% \mathrm{CI}=$ 1.26-1.75; E4/4 versus E3/3: OR $=1.45$, 95\% CI $=1.23-1.71$ ).

In the subgroups, the results showed evidence of significant association between Apo E gene polymorphism and $\mathrm{CHD}$ risk in the genetic model of E3/4 and E4/4 compared with the genotype E3/3 in eight Mongolian studies (E3/4 versus $\mathrm{E} 3 / 3$ : $\mathrm{OR}=1.73,95 \% \mathrm{CI}=1.02-2.93 ; \mathrm{E} 4 / 4$ versus $\mathrm{E} 3 / 3: \mathrm{OR}=2.78,95 \% \mathrm{CI}=1.35-5.72$ ), while the variant genotypes ApoEE2/2, E2/3, and E2/4 were not associated with the increased risk of $\mathrm{CHD}(\mathrm{E} 2 / 2$ versus $\mathrm{E} 3 / 3$ : $\mathrm{OR}=1.08,95 \%$
$\mathrm{CI}=0.39-3.00 ; \mathrm{E} 2 / 3$ versus $\mathrm{E} 3 / 3: \mathrm{OR}=1.16,95 \% \mathrm{CI}=0.91-$ 1.49; $\mathrm{E} 2 / 4$ versus $\mathrm{E} 3 / 3$ : $\mathrm{OR}=1.38,95 \% \mathrm{CI}=0.62-3.11)$. In 22 Caucasians studies, significant associations were found in three genetic models (E2/3 versus $\mathrm{E} 3 / 3$ : $\mathrm{OR}=0.81,95 \% \mathrm{CI}$ $=0.67-0.98 ; \mathrm{E} 3 / 4$ versus $\mathrm{E} 3 / 3 \mathrm{O} \mathrm{OR}=1.38,95 \% \mathrm{CI}=1.17-1.62$; $\mathrm{E} 4 / 4$ versus $\mathrm{E} 3 / 3$ : $\mathrm{OR}=1.51,95 \% \mathrm{CI}=1.12-2.04)$; carriers with ApoEE2/2 and E2/4 were not associated with the significant risk of $\mathrm{CHD}(\mathrm{E} 2 / 2$ versus $\mathrm{E} 3 / 3: \mathrm{OR}=1.03,95 \% \mathrm{CI}=0.78-1.35$; $\mathrm{E} 2 / 4$ versus $\mathrm{E} 3 / 3$ : $\mathrm{OR}=1.02,95 \% \mathrm{CI}=0.86-1.22$ ).

Besides, carriers with $A p o E \varepsilon 2$ allele had no significantly decreased risk of $\mathrm{CHD}$ compared with individuals with the $\varepsilon 3$ allele in the random-effect model $(\mathrm{OR}=0.91 ; 95 \% \mathrm{CI}=$ 0.81-1.03). Stratified analysis on the descent also showed no evidence on the $\varepsilon 2$ allele variant and CHD risk in Mongolians $(\mathrm{OR}=1.18,95 \% \mathrm{CI}=0.94-1.46)$, but there had a decrease risk in Caucasians $(\mathrm{OR}=0.84,95 \% \mathrm{Cl}=0.74-0.96)$. In addition, compared with the $A p o E \varepsilon 3$ allele, carriers with the $\varepsilon 4$ allele had a $46 \%$ increased risk of CHD in the random-effect model 


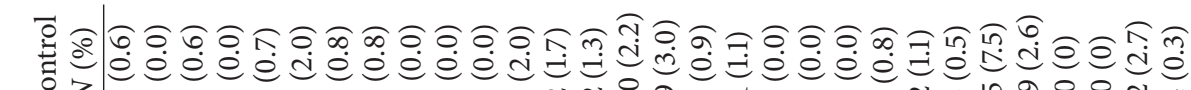
$\underset{H}{\stackrel{4}{H}}$

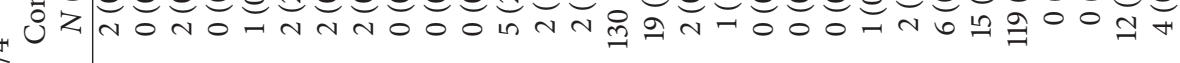

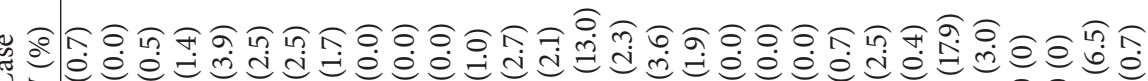

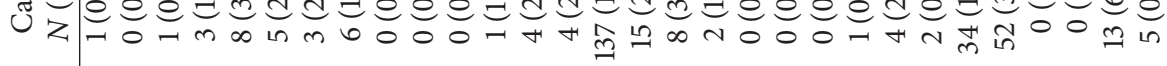

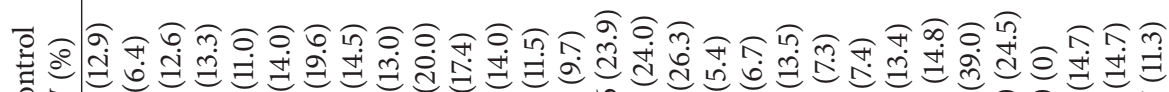
$\stackrel{+}{\stackrel{4}{m}}$

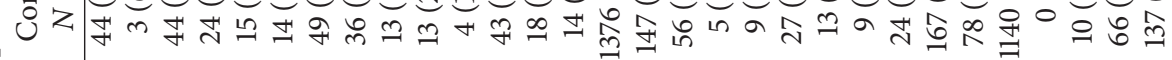

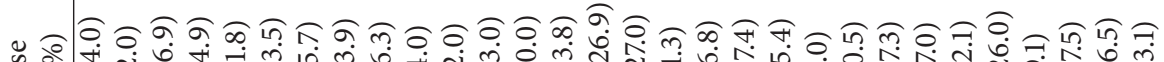
U

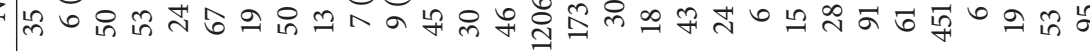

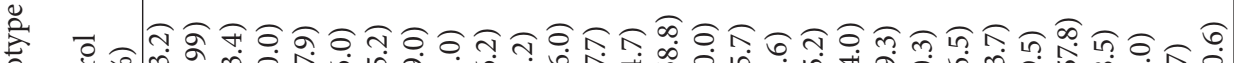
青

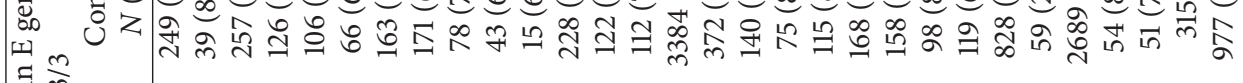

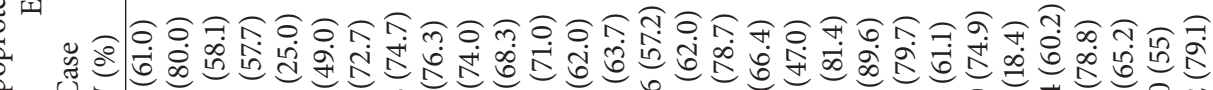
$\checkmark$ 之 范

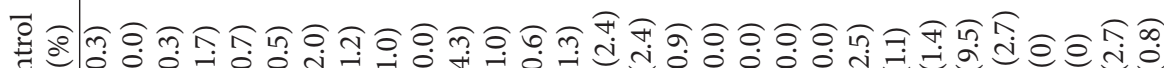

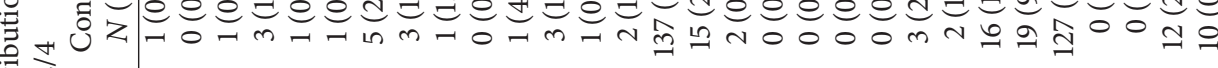
娄 조

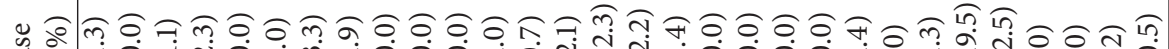

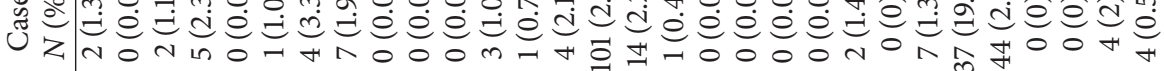

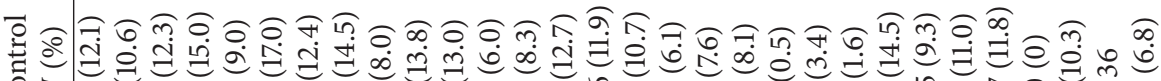
$\stackrel{\infty}{\sim}$

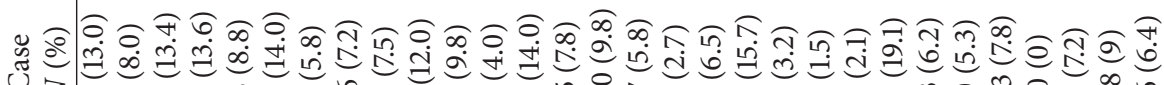

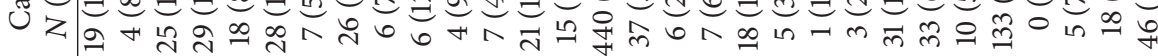

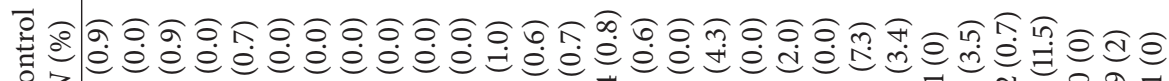
त्ञ

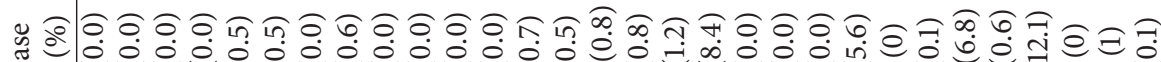

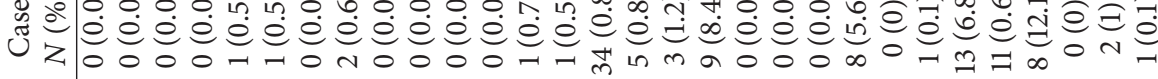

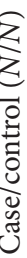

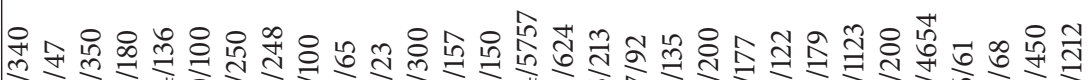

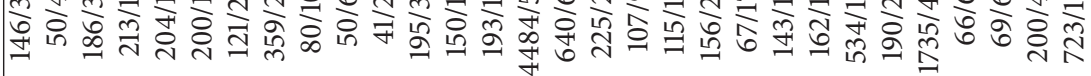
Uั

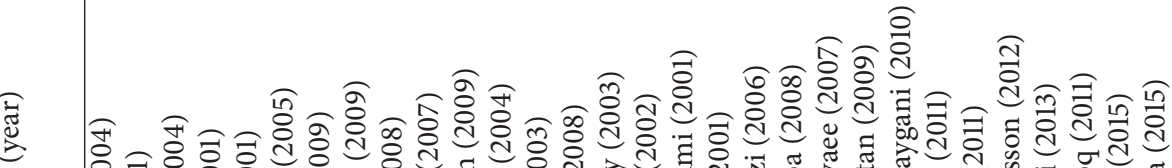

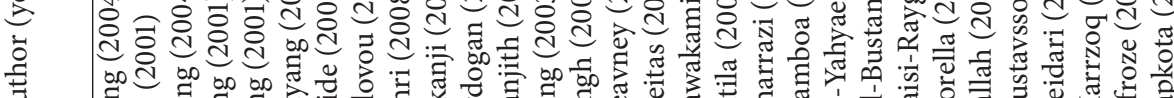
志 等

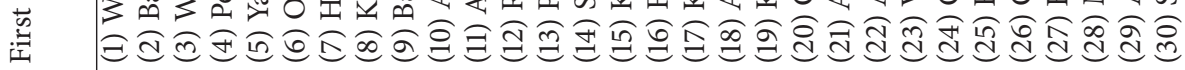




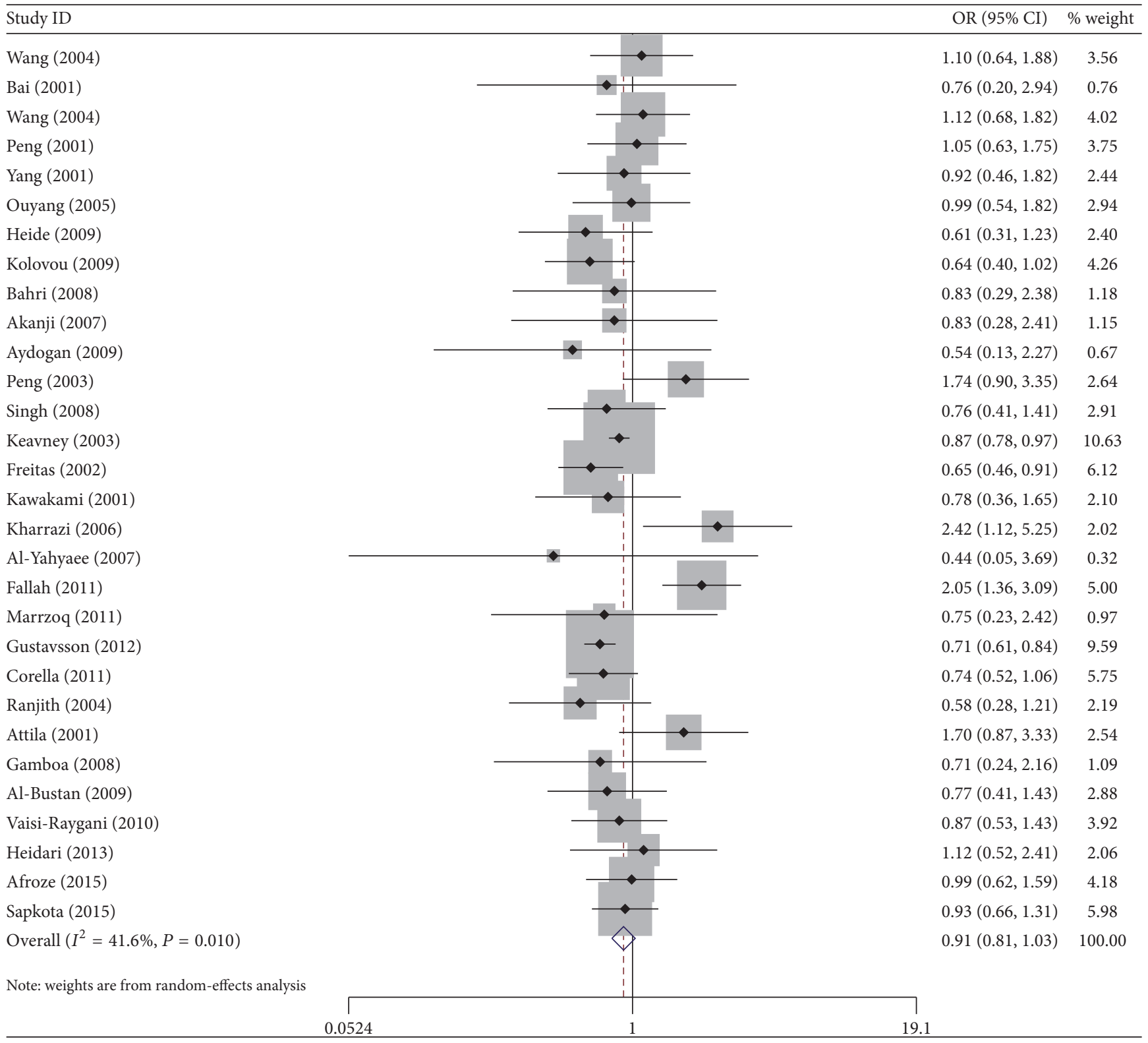

FIgURE 2: ORs of CHD associated with Apo E for the allele $\varepsilon 2$ compared with the $\varepsilon 3$.

$(\mathrm{OR}=1.46,95 \% \mathrm{CI}=1.28-1.66)$, and the effects were more evident in the Mongolians (the random-effects model OR = 2.29, 95\% CI $=1.89-2.77$ ) and mild in the Caucasians (the fixed-effects model OR $=1.25,95 \% \mathrm{CI}=1.11-1.41$ ).

3.3. Sensitivity Analysis. We conducted a sensitivity analysis on the Apo E polymorphisms and risk of CHD excluding studies deviating from HWE among controls. The pooled ORs estimates were similar with that of excluded studies, so the results were not shown.

3.4. Bias Diagnostics. For the ApoEc2 versus $\varepsilon 3$ allele, the shape of the funnel plot seemed symmetrical (Figure 4 ), and then Egger's test showed no evidence of publication bias $(P=$ 0.211 ), and the fail-safe number also showed no publication bias in this meta-analysis $\left(\mathrm{N}_{\mathrm{fs}}(0.05)=381.51, \mathrm{~N}_{\mathrm{fs}}(0.01)=\right.$ 173.87).

For the $A p o E \varepsilon 4$ compared with $\varepsilon 3$ allele, the shape of the funnel plots seemed asymmetrical (Figure 4), and Egger's test revealed there was a significant publication bias $(P=0.003)$. By using the trim and fill method, we showed that OR and 95\% CI did not change. Besides, the fail-safe number also suggested that the result of the meta-analysis was stability $\left(\mathrm{N}_{\mathrm{fs}}(0.05)=1218.31, \mathrm{~N}_{\mathrm{fs}}(0.01)=588.44\right)$.

\section{Discussion}

Apolipoprotein E (Apo E) is one of the most major apolipoproteins in the central nervous system, with functions of neurons repair. Apo E genetic variants showed significant 


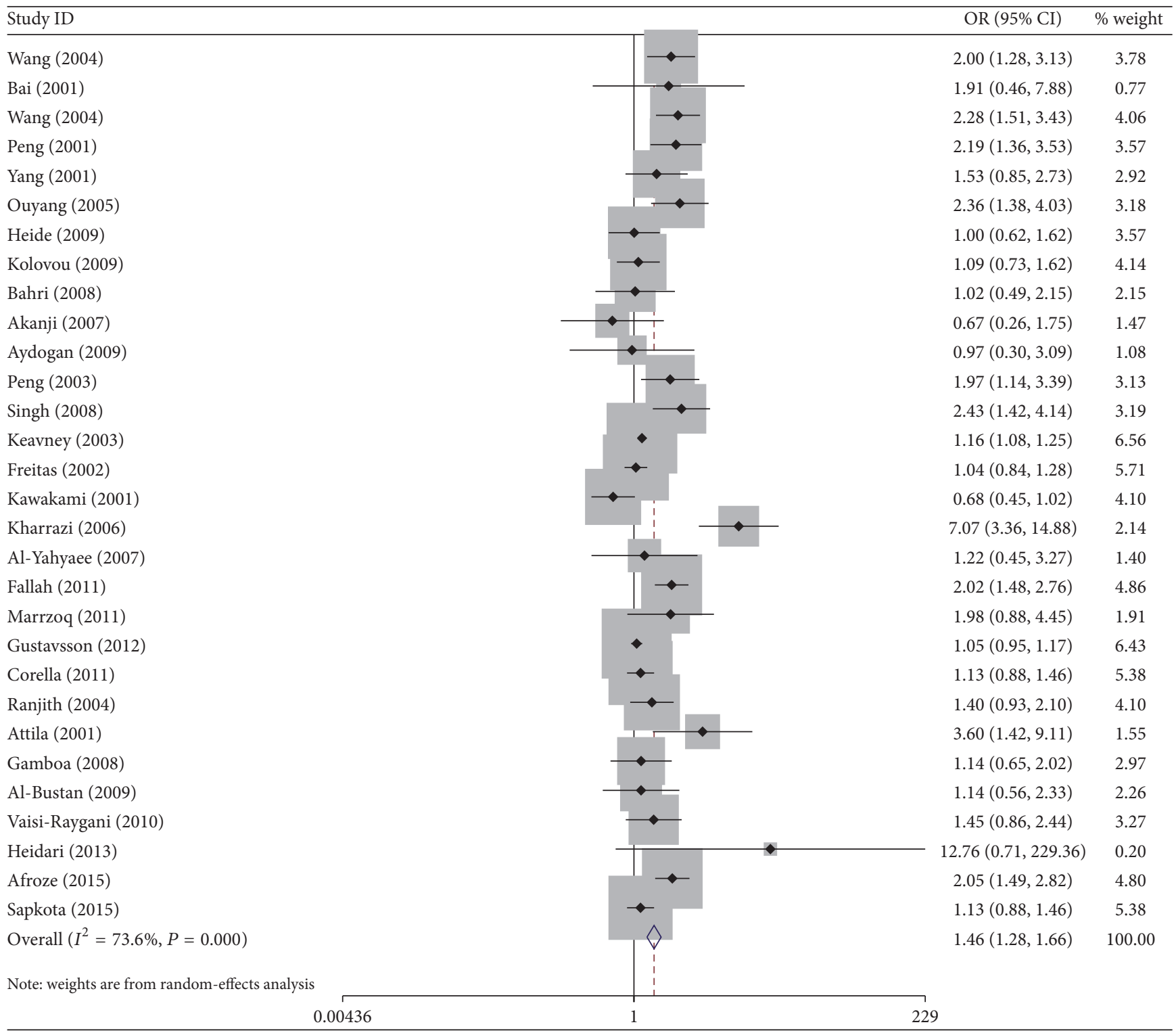

FIgURE 3: ORs of CHD associated with Apo E for the allele $\varepsilon 4$ compared with the $\varepsilon 3$.
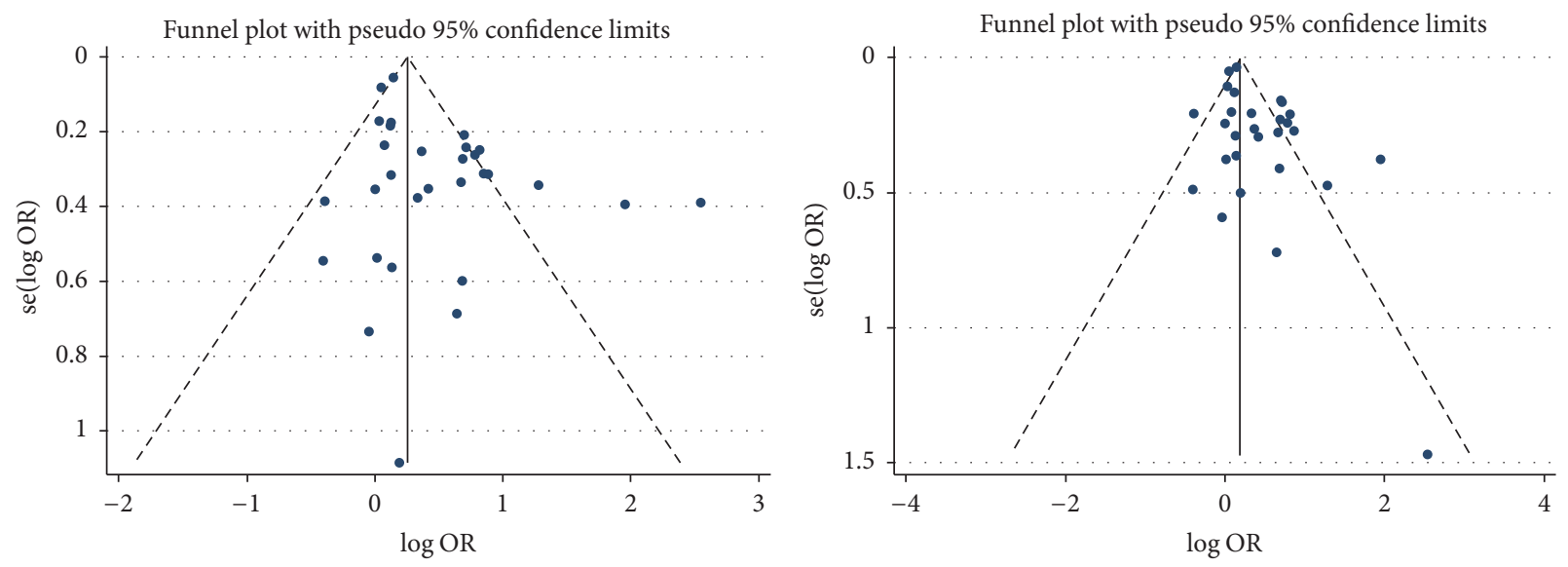

Figure 4: The funnel plot of the Apo E allele $\varepsilon 2$ and $\varepsilon 4$ compared with the $\varepsilon 3$. 
associations with the risks of nervous system degenerative diseases, including Alzheimer's disease, vascular dementia, and cerebrovascular disease [48, 49]. Apo E gene as a receptor-binding ligand mediating the clearance of chylomicron and remnants of very-low-density lipoprotein cholesterol from plasma also plays a major role in the metabolisms of cholesterol and triglyceride. Functional variants of genes encoding lipoproteins are responsible in part for betweenindividual variation in the plasma levels of lipoproteins.

Apo $E$ with 3 major isoforms, E2, E3, and E4, which are coded by the corresponding alleles, $\varepsilon 2, \varepsilon 3$, and $\varepsilon 4$, has 6 genotypes, E2/2, E2/3, E2/4, E3/3, E3/4, and E4/4. Compared with $\varepsilon 3$ carriers, carriers of the $\varepsilon 2$ allele, which has defective receptor-binding ability, have lower circulating cholesterol levels and higher triglyceride levels, whereas carriers of the $\varepsilon 4$ allele appear to have higher plasma levels of total and lowdensity lipoprotein cholesterol [50-52]. In serum or plasma cholesterol of healthy Caucasians, Apo E polymorphisms accounted for approximately $2 \%-11 \%$ of the total [53]. Recent evidences also indicated that Apo E may play additional roles in the development of CHD through macrophage cholesterol efflux, platelet aggregation, and allele-specific antioxidant and immune activities [53-55].

A lot of epidemiologic studies have investigated the relation between Apo E genotypes and CHD risk in the general population. Apo E polymorphisms are believed to confer susceptibility to CHD risk. In 1992, a meta-analysis of 27 studies reported that the subjects carrying the $\varepsilon 2$ and $\varepsilon 4$ alleles had, respectively, lower and higher plasma cholesterol values than subjects carrying the E3/3 genotype, which suggested that the $A p o E \varepsilon 4$ allele may, in individuals with the ApoEE4/3 phenotype, be a risk factor of cardiovascular disease [12]. The last meta-analysis of 14 published case-control studies in 2015 showed that carriers with $P O E \varepsilon 2$ allele were associated with the decreased risk for CHD (OR $=0.82,95 \% \mathrm{CI}$ : 0.75-0.90) compared with those carrying $\varepsilon 3$ allele, while those with $\varepsilon 4$ allele had a significant increased risk for CHD (OR $=1.34$, 95\% CI: 1.15-1.57) [15].

In this 30 studies' meta-analysis including 11,804 CHD patients and 17,713 controls, we identified a significant increased risk for CHD among carriers of the ApoEE3/4 and E4/4 genotypes compared with carriers of the E3/3 genotype, but no significant evidence was found between the variant genotypes of $A p o E E 2 / 3, \mathrm{E} 2 / 4$, and E2/2 and CHD risk. In the stratified analyses by descent, for the $\varepsilon 4$ allele genetic variant, the effect was more evident in the Mongolians group and mild in Caucasians group, which showed that the ApoEc4 allele genetic variant modulated the increased risk of $\mathrm{CHD}$ with the differences of genetic background. Moreover, there was a decreased risk in Caucasians between the $\varepsilon 2$ allele variant and CHD risk but no evidence in Mongolians; further studies should be conducted to verify it.

Our study has several limitations. First, as with all metaanalyses, although we did Egger's test and calculated the failsafe number to evaluate the publication bias, it might have occurred because our analyses were all based on published studies. For the ApoEc4 compared with $\varepsilon 3$ allele, the Egger test showed existence of publication bias, but from the results of the trim and fill method and the fail-safe number, the publication bias and the possibility of false positive were relatively small. Second, the control group of some studies was not in conformity with Hardy-Weinberg equilibrium. But, in sensitivity analysis, the pooled estimates were similar after we excluded studies deviating from Hardy-Weinberg equilibrium among controls; therefore these studies were included in the final analysis. Gene-environment interactions may have contributed to the CHD. Apo E gene is a candidate gene and a common one to study gene-environment interactions. However, because of lack of the original data of the meta-analysis, further evaluation of potential gene-gene and gene-environment interactions was limited.

In conclusion, it was showed in this meta-analysis that $A p o E \varepsilon 4$ allele polymorphism may contribute to the individual susceptibility of CHD. Further rigorous design, large sample of case-control, or prospective study are required to continue in-depth evaluation on gene-gene and gene-environment interactions on Apo E polymorphisms and CHD risk.

\section{Competing Interests}

The authors declare that they have no competing interests.

\section{Authors' Contributions}

Min $\mathrm{Xu}$ and Jun Zhao equally contributed to the article.

\section{Acknowledgments}

This study was supported by the "Five-Twelfth" National Science and Technology Support Program (no. 2012BAI41B08 and no. 2013BAI12B01) and the National Natural Science Foundation of China (81673259).

\section{References}

[1] J. Zhou, X. Chen, H. Ye et al., "An association study between genetic polymorphism in the interleukin-6 receptor gene and coronary heart disease," BioMed Research International, vol. 2014, Article ID 504727, 6 pages, 2014.

[2] E. F. A. E. Halim, A. A. Reda, A. A. K. Hendi, S. A. Zaki, E. S. Essa, and A. S. Khalifa, "Apolipoprotein E gene variants as a risk factor for coronary artery disease in type 2 diabetic Egyptian patients," The Egyptian Journal of Immunology, vol. 19, no. 1, pp. $1-10,2012$.

[3] G. D. Kolovou, D. B. Panagiotakos, V. Kolovou et al., "Common variants of apolipoprotein $\mathrm{E}$ and cholesteryl ester transport protein genes in male patients with coronary heart disease and variable body mass index," Angiology, vol. 66, no. 2, pp. 169-173, 2015.

[4] R. Roberts and A. F. R. Stewart, "Genes and coronary artery disease: where are we?" Journal of the American College of Cardio$\log y$, vol. 60, no. 18, pp. 1715-1721, 2012.

[5] X. Mi, K. M. Eskridge, V. George, and D. Wang, "Structural equation modeling of gene-environment interactions in coronary heart disease," Annals of Human Genetics, vol. 75, no. 2, pp. 255-265, 2011.

[6] P. Jeemon, K. Pettigrew, C. Sainsbury, D. Prabhakaran, and S. Padmanabhan, "Implications of discoveries from genome-wide association studies in current cardiovascular practice," World Journal of Cardiology, vol. 3, no. 7, pp. 230-247, 2011. 
[7] V. Bañares, D. Wyszynski, L. Schreier, and M. Tavella, "APOE -219G/T polymorphism related to serum lipid levels in atherosclerotic patients from Argentina," Investigacion Clinica, vol. 51, no. 1, pp. 17-26, 2010.

[8] J. T. Bazzaz, M. Nazari, H. Nazem et al., "Apolipoprotein E gene polymorphism and total serum cholesterol level in Iranian population," Journal of Postgraduate Medicine, vol. 56, no. 3, pp. 173-175, 2010.

[9] G. Ken-Dror, P. J. Talmud, S. E. Humphries, and F. Drenos, "APOE/C1/C4/C2 gene cluster genotypes, haplotypes and lipid levels in prospective coronary heart disease risk among UK healthy men," Molecular Medicine, vol. 16, no. 9-10, pp. 389-399, 2010.

[10] F. Takeuchi, M. Isono, T. Katsuya et al., "Association of genetic variants influencing lipid levels with coronary artery disease in Japanese individuals," PLoS ONE, vol. 7, no. 9, article e46385, 2012.

[11] M. D. Waltmann, J. E. Basford, E. S. Konaniah, N. L. Weintraub, and D. Y. Hui, "Apolipoprotein E receptor-2 deficiency enhances macrophage susceptibility to lipid accumulation and cell death to augment atherosclerotic plaque progression and necrosis," Biochimica et Biophysica Acta (BBA)_Molecular Basis of Disease, vol. 1842, no. 9, pp. 1395-1405, 2014.

[12] J. Dallongeville, S. Lussier-Cacan, and J. Davignon, "Modulation of plasma triglyceride levels by apoE phenotype: a metaanalysis," Journal of Lipid Research, vol. 33, no. 4, pp. 447-454, 1992.

[13] P. W. F. Wilson, E. J. Schaefer, M. G. Larson, and J. M. Ordovas, "Apolipoprotein E alleles and risk of coronary disease: a metaanalysis," Arteriosclerosis, Thrombosis, and Vascular Biology, vol. 16, no. 10, pp. 1250-1255, 1996.

[14] A. N. Cheema, A. Bhatti, X. Wang et al., "APOE gene polymorphism and risk of coronary stenosis in Pakistani population," BioMed Research International, vol. 2015, Article ID 587465, 5 pages, 2015.

[15] Y. Zhang, H. Q. Tang, W. J. Peng, B. B. Zhang, and M. Liu, "Meta-analysis for the association of apolipoprotein E epsilon2/ epsilon3/epsilon4 polymorphism with coronary heart disease," Chinese Medical Journal, vol. 128, pp. 1391-1398, 2015.

[16] M.-D. Zhang, W. Gu, S.-B. Qiao, E.-J. Zhu, Q.-M. Zhao, and S.-Z. Lv, "Apolipoprotein e gene polymorphism and risk for coronary heart disease in the chinese population: a meta-analysis of 61 studies including 6634 cases and 6393 controls," PLoS ONE, vol. 9, no. 4, article e95463, 2014.

[17] L. F. Marrzoq, F. A. Sharif, and A. A. Abed, "Relationship between ApoE gene polymorphism and coronary heart disease in Gaza Strip," Journal of Cardiovascular Disease Research, vol. 2, no. 1, pp. 29-35, 2011.

[18] C.-H. Wang, X. Zhou, G.-D. Zhou, D.-F. Han, and F. Zheng, "Interaction of ApoE and LDL-R gene polymorphisms and alcohol drinking and smoking on coronary heart disease," Zhonghua Yi Xue Za Zhi, vol. 84, no. 7, pp. 554-558, 2004.

[19] X. Bai, M. Zhao, and B. Wang, "Dyslipidemia-related risk factors for myocardial infarction and polymorphism of ApoE gene among myocardial infarction patients and their siblings," Zhonghua yi xue za zhi, vol. 81, no. 6, pp. 340-343, 2001.

[20] C.-H. Wang, X. Zhou, G.-D. Zhou et al., "Genetic association of apoE and apoCI gene polymorphisms with coronary heart disease," Zhonghua Liu Xing Bing Xue Za Zhi, vol. 25, no. 11, pp. 982-985, 2004

[21] S. Peng, J. Peng, and W. Gong, "Association of apolipoprotein E gene polymorphism with early-onset coronary heart disease and its effect on plasma lipid levels," Zhonghua Yi Xue Yi Chuan Xue Za Zhi, vol. 18, no. 5, pp. 375-378, 2001.

[22] Z. Yang, T. Zhu, G. Ma et al., "Apolipoprotein E polymorphism in the early onset of coronary heart disease," Chinese Medical Journal, vol. 114, no. 9, pp. 983-985, 2001.

[23] T. Ouyang, J.-N. Song, Y. Miao et al., "Study on relationship between polymorphism of apolipoprotein E gene and syndromes of phlegm and blood stasis in patients with coronary heart disease," Zhong Xi Yi Jie He Xue Bao, vol. 3, no. 6, pp. 438442, 2005.

[24] S. Heide, K. Manfred, C. Gläser, and S. Schulz, "Apolipoprotein E (apoE) polymorphism: a risk factor for fatal coronary sclerosis?" Forensic Science International, vol. 192, no. 1-3, pp. 62-66, 2009.

[25] G. D. Kolovou, K. K. Anagnostopoulou, P. Kostakou et al., "Apolipoprotein E gene polymorphism and obesity status in middle-aged men with coronary heart disease," In Vivo, vol. 23, no. 1, pp. 33-39, 2009.

[26] R. Bahri, E. Esteban, P. Moral, M. Hassine, K. B. Hamda, and H. Chaabani, "Apolipoprotein gene polymorphisms and plasma levels in healthy Tunisians and patients with coronary artery disease," Lipids in Health and Disease, vol. 7, article 46, 2008.

[27] A. O. Akanji, C. G. Suresh, H. R. Fatania, R. Al-Radwan, and M. Zubaid, "Associations of apolipoprotein E polymorphism with low-density lipoprotein size and subfraction profiles in Arab patients with coronary heart disease," Metabolism: Clinical and Experimental, vol. 56, no. 4, pp. 484-490, 2007.

[28] H. Y. Aydogan, S. Isbir, O. Kurnaz, U. Gormus, and T. Isbir, "Associations of lipoprotein lipase S447X and apolipoprotein E genotypes with low-density lipoprotein subfractions in Turkish patients with coronary artery disease," In Vivo, vol. 23, pp. 155$161,2009$.

[29] N. Ranjith, R. J. Pegoraro, L. Rom, M. C. Rajput, and D. P. Naidoo, "Lp(a) and apoE polymorphisms in young South African Indians with myocardial infarction," Cardiovascular Journal of South Africa, vol. 15, no. 3, pp. 111-117, 2004.

[30] D.-Q. Peng, S.-P. Zhao, S. Nie, and J. Li, "Gene-gene interaction of PPAR $\gamma$ and ApoE affects coronary heart disease risk," International Journal of Cardiology, vol. 92, no. 2-3, pp. 257-263, 2003.

[31] P. Singh, M. Singh, D. Bhatnagar, T. Kaur, and S. Gaur, "Apolipoprotein E polymorphism and its relation to plasma lipids in coronary heart disease," Indian Journal of Medical Sciences, vol. 62, no. 3, pp. 105-112, 2008.

[32] B. Keavney, S. Parish, A. Palmer et al., "Large-scale evidence that the cardiotoxicity of smoking is not significantly modified by the apolipoprotein E $\varepsilon 2 / \varepsilon 3 / \varepsilon 4$ genotype," The Lancet, vol. 361, no. 9355, pp. 396-398, 2003.

[33] E. M. Freitas, T. C. A. Phan, C. E. Herbison, F. T. Christiansen, R. R. Taylor, and F. M. Van Bockxmeer, "The poliovirus receptor related 2 (PRR2) and apolipoprotein E genes and coronary heart disease," Journal of Cardiovascular Risk, vol. 9, no. 1, pp. 59-65, 2002.

[34] K. Kawakami, K. Okumura, H. Matsui et al., "The apolipoprotein E genotype influences the risk for vasospastic angina," Canadian Journal of Cardiology, vol. 17, no. 6, pp. 660-666, 2001.

[35] G. Attila, E. Acartürk, G. Eskandari et al., "Effects of apolipoprotein E genotypes and other risk factors on the development of coronary artery disease in Southern Turkey," Clinica Chimica Acta, vol. 312, no. 1-2, pp. 191-196, 2001. 
[36] H. Kharrazi, A. Vaisi Raygani, A. R. Sabokroh, and T. Pourmotabbed, "Association between apolipoprotein E polymorphism and coronary artery disease in the Kermanshah population in Iran," Clinical Biochemistry, vol. 39, no. 6, pp. 613-616, 2006.

[37] R. Gamboa, C. Huesca-Gómez, O. Pérez-Méndez et al., "Apolipoprotein E polymorphisms in Mexican patients with coronary artery disease," Clinical Chemistry and Laboratory Medicine, vol. 46, no. 4, pp. 481-485, 2008.

[38] S. A. S. Al-Yahyaee, S. S. Ganguly, M. N. Al-Kindi, and A. I. Al-Bahrani, "Apolipoprotein E polymorphism in omani dyslipidemic patients with and without coronary artery disease," Human Biology, vol. 79, no. 1, pp. 93-102, 2007.

[39] S. A. Al-Bustan, M. Alkhalaf, I. Al-Rashdan et al., "Apolipoprotein $\mathrm{E}, \mathrm{CI}$ and $\mathrm{B}$ gene polymorphisms in a sample of patients with coronary heart disease in the Kuwaiti population," Medical Principles and Practice, vol. 18, no. 4, pp. 294-299, 2009.

[40] A. Vaisi-Raygani, Z. Rahimi, H. Tavilani, and T. Pourmotabbed, "Butyrylcholinesterase $\mathrm{K}$ variant and the APOE- $\varepsilon 4$ allele work in synergy to increase the risk of coronary artery disease especially in diabetic patients," Molecular Biology Reports, vol. 37, no. 4, pp. 2083-2091, 2010.

[41] D. Corella, O. Portolés, L. Arriola et al., "Saturated fat intake and alcohol consumption modulate the association between the APOE polymorphism and risk of future coronary heart disease: a nested case-control study in the Spanish EPIC cohort," Journal of Nutritional Biochemistry, vol. 22, no. 5, pp. 487-494, 2011.

[42] S. Fallah, M. Seifi, M. Firoozrai, L. Hosainnee Ghohari, A. Samadikuchaksaraei, and B. Samadirad, "Effect of Apolipoprotein E genotypes on incidence and development of coronary stenosis in Iranian patients with coronary artery disease," Journal of Clinical Laboratory Analysis, vol. 25, no. 1, pp. 43-46, 2011.

[43] J. Gustavsson, K. Mehlig, K. Leander et al., "Interaction of apolipoprotein $\mathrm{E}$ genotype with smoking and physical inactivity on coronary heart disease risk in men and women," Atherosclerosis, vol. 220, no. 2, pp. 486-492, 2012.

[44] J. Machal, A. Vasku, O. Hlinomaz, P. Linhartova, L. Groch, and J. Vitovec, "Apolipoprotein E polymorphism is associated with both number of diseased vessels and extent of coronary artery disease in Czech patients with CAD," Biomedical Papers, vol. 156, no. 2, pp. 151-158, 2012.

[45] M. M. Heidari, S. K. Foruzannia, M. Khatami, M. Hadadzadeh, and M. Emami Meybodi, "Apolipoprotein E gene polymorphism in Iranian coronary atherosclerosis patients candidate for coronary artery bypass graft," Iranian Journal of Basic Medical Sciences, vol. 16, no. 7, pp. 841-844, 2013.

[46] D. Afroze, A. Yousuf, N. A. Tramboo, Z. A. Shah, and A. Ahmad, "ApoE gene polymorphism and its relationship with coronary artery disease in ethnic Kashmiri population," Clinical and Experimental Medicine, vol. 16, no. 4, pp. 551-556, 2016.

[47] B. Sapkota, A. Subramanian, G. Priamvada et al., "Association of APOE polymorphisms with diabetes and cardiometabolic risk factors and the role of APOE genotypes in response to antidiabetic therapy: results from the AIDHS/SDS on a South Asian population," Journal of Diabetes and Its Complications, vol. 29, no. 8, pp. 1191-1197, 2015.

[48] M. Liu, C. Bian, J. Zhang, and F. Wen, "Apolipoprotein E gene polymorphism and Alzheimer's disease in Chinese population: a meta-analysis," Scientific Reports, vol. 4, article 4383, 2014.

[49] Y. Liu, J.-T. Yu, H.-F. Wang et al., "APOE genotype and neuroimaging markers of Alzheimer's disease: systematic review and meta-analysis," Journal of Neurology, Neurosurgery and Psychiatry, vol. 86, no. 2, pp. 127-134, 2015.

[50] R. Chaudhary, A. Likidlilid, T. Peerapatdit et al., "Apolipoprotein E gene polymorphism: effects on plasma lipids and risk of type 2 diabetes and coronary artery disease," Cardiovascular Diabetology, vol. 11, article 36, 2012.

[51] J. Davignon, R. E. Gregg, and C. F. Sing, "Apolipoprotein E polymorphism and atherosclerosis," Arteriosclerosis, vol. 8, no. 1, pp. 1-21, 1988.

[52] J. Davignon, J. S. Cohn, L. Mabile, and L. Bernier, "Apolipoprotein E and atherosclerosis: insight from animal and human studies," Clinica Chimica Acta, vol. 286, no. 1-2, pp. 115-143, 1999.

[53] M. H. Moghadasian, B. M. McManus, L. B. Nguyen et al., "Pathophysiology of apolipoprotein E deficiency in mice: relevance to apo E-related disorders in humans," The FASEB Journal, vol. 15, no. 14, pp. 2623-2630, 2001.

[54] A. K. Stannard, D. R. Riddell, S. M. Sacre et al., "Cell-derived Apolipoprotein E (ApoE) particles inhibit vascular cell adhesion molecule-1 (VCAM-1) expression in human endothelial cells," Journal of Biological Chemistry, vol. 276, no. 49, pp. 4601146016, 2001.

[55] L. G. Shewan and A. J. S. Coats, "Ethics in the authorship and publishing of scientific articles," International Journal of Cardiology, vol. 144, no. 1, pp. 1-2, 2010. 


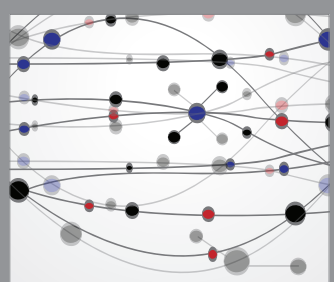

The Scientific World Journal
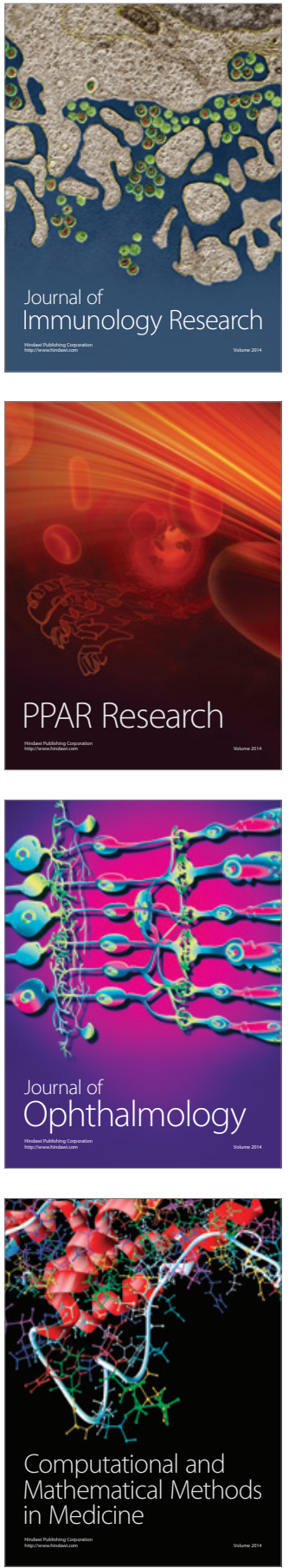

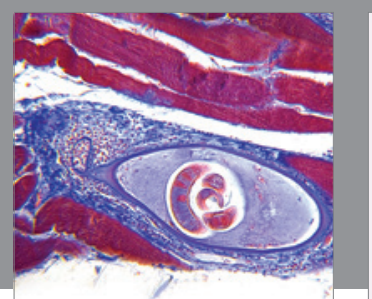

Gastroenterology Research and Practice

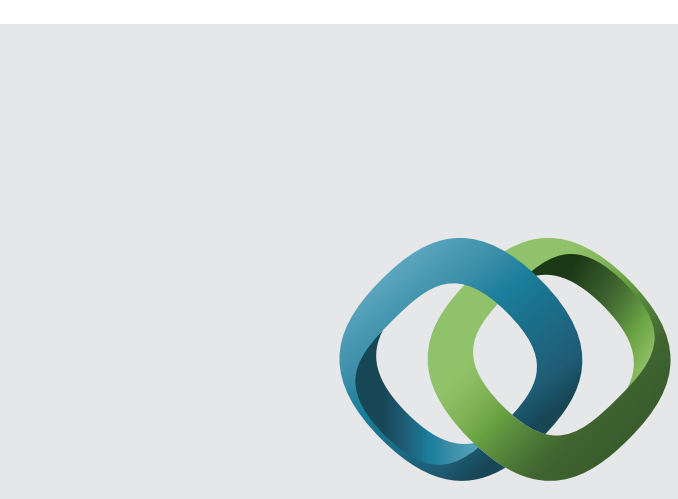

\section{Hindawi}

Submit your manuscripts at

http://www.hindawi.com
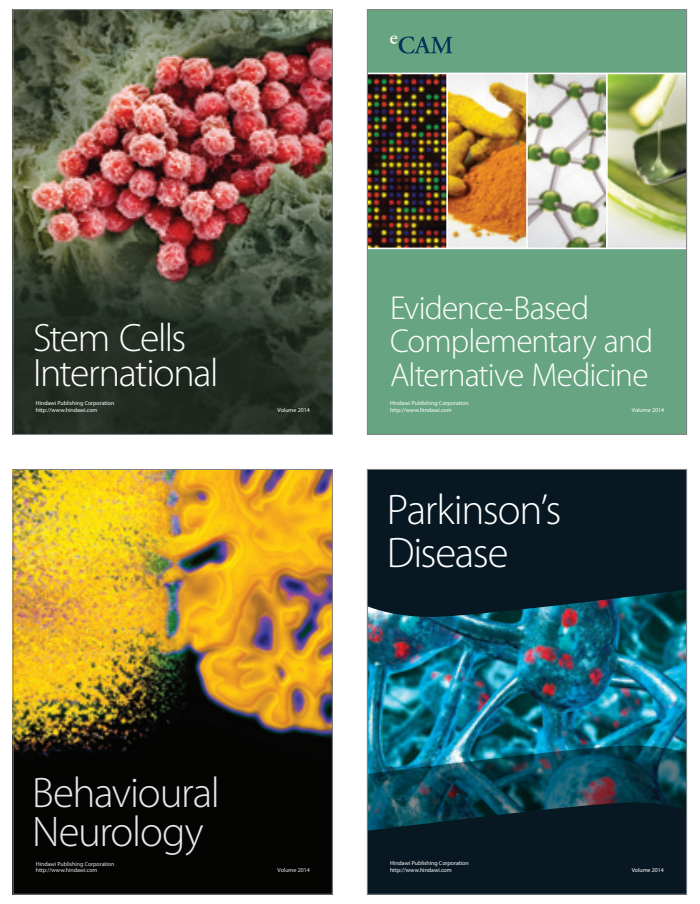
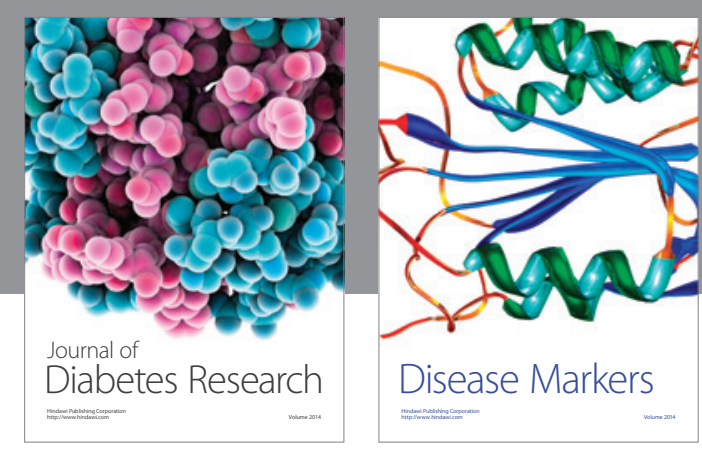

Disease Markers
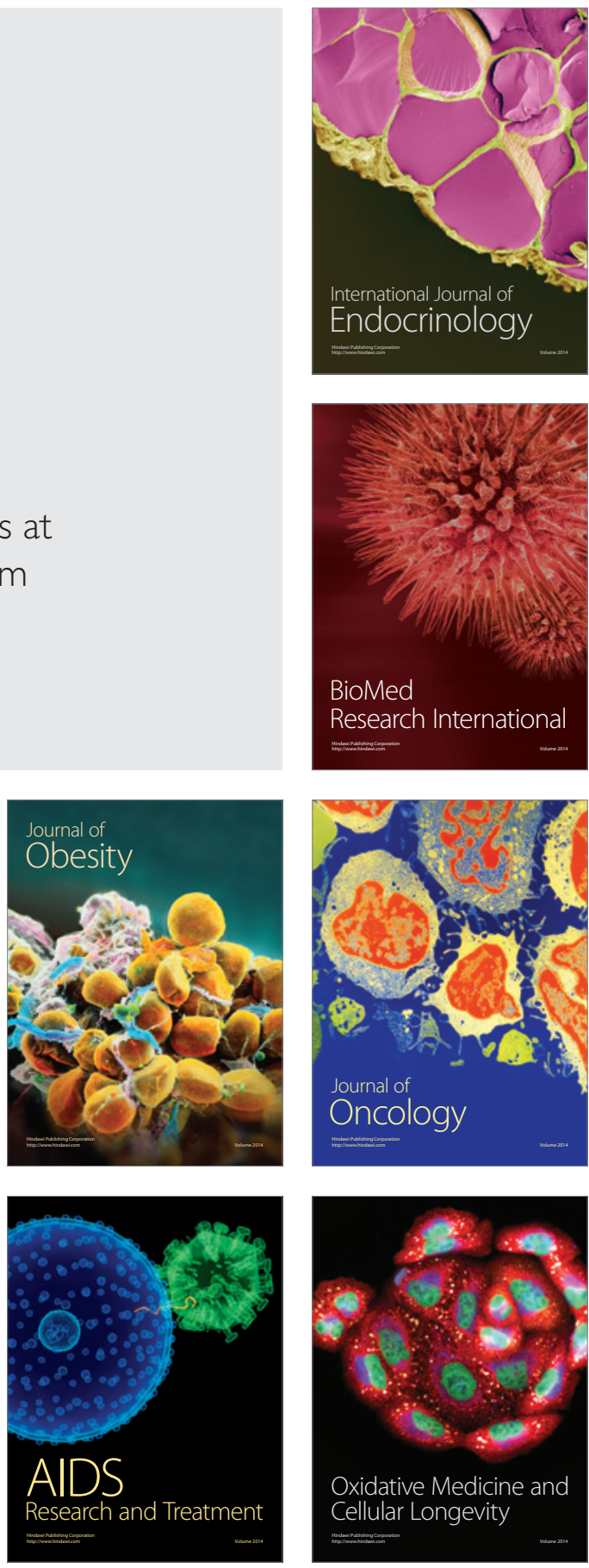